\title{
EFEKTIFITAS BIMBINGAN KELOMPOK BERBASIS BUDAYA JAWA UNTUK MENINGKATKAN KOMUNIKASI INTERPERSONAL SISWA SMK PGRI WONOASRI
}

\author{
Rischa Pramudia Trisnani* \\ rischa_pramudia@yahoo.com \\ Silvia Yula Wardani* \\ via.ardhani@gmail.com \\ Ferisia Hana** \\ ferisia_hp@yahoo.com
}

\begin{abstract}
Abstrak
Berkomunikasi dengan orang lain dapat dilakukan individu di dalam lingkungan keluarga, sekolah dan masyarakat. Komunikasi antara dua orang atau lebih secara tatap muka disebut komunikasi interpersonal.Siswa SMK umumnya berkisar (16-19 th) dimana usia berada pada tahap usia remaja, yang mana salah satu tugas perkembangan yang harus dicapai adalah mengembangkan keterampilan komunikasi interpersonal.Berdasarkan hasil wawancara dengan guru BK SMK PGRI Wonoasri menunjukkan bahwa: (1) masih ada beberapa siswa yang berkomunikasi interpersonal kurang baik, (2) terjadi perselisihan antar siswa karena kesalahpahaman yang disebabkan komunikasi interpersonal yang kurang baik. Untuk meningkatkan komunikasi salah satu caranya adalah dengan menerapkan layanan bimbingan kelompok berbasis budaya jawa, sehingga siswa mampu berkomunikasi dengan baik dan sopan sesuai ajaran budaya jawa yang terkenal halus dan sopan. Tujuan penelitian ini adalah untuk mengerahui efektifitas bimbingan kelompok berbasis budaya jawa dalam meningkatkan komunikasi interpersonal siswa SMK PGRI Wonoasri.

Penelitian ini dilakukan di SMK PGRI Wonoasri dengan desain penelitian pre-experimental design. Teknik pengumpulan data menggunakan skala psikologis yaitu skala komunkasi interpersonal. Teknik analisis data menggunakan Wilcoxon Match Pairs Test.

Hasil penelitian menunjukkan bimbingan kelompok berbasis budaya jawa efektif untuk meningkatkan komunikasi interpersonal siswa SMK terbukti setelah uji hipotetik dengan teknik analisis Wilcoxon Signed Rank Test nilai AsympSig (2-tailed) / asympiotic significance0.012, dapat disimpulkan bahwa bimbingan kelompok berbasis budaya jawa efektif untuk meningkatkan komunikasi interpersonal siswa SMK di Kabupaten Madiun. Disarankan untuk meningkatkan pelayanan bimbingan dan konseling perlu pengembangkan layanan bimbingan dan konseling salah satunya adalah bimbingan kelompok.
\end{abstract}

Kata kunci : Bimbingan Kelompok, budaya Jawa, Komunikasi Interpersonal

*Rischa Pramudia T dan Silvia Yula W adalah adalah Dosen Program Studi Bimbingan dan Konseling Fakultas Ilmu Pendidikan IKIP PGRI MADIUN.

** Ferisia Hana P adalah adalah Mahasiswa Program Studi Bimbingan dan Konseling Fakultas Ilmu Pendidikan IKIP PGRI MADIUN. 


\section{A. Pendahuluan}

Di dalam kehidupan bermasyarakat, manusia menjalankan peranannya sebagai makhluk sosial. Sebagai makhluk sosial, manusia akan selalu berkeinginan untuk berbicara, tukar menukar gagasan, memberikan informasi dan menerima informasi, berbagi pengalaman, bekerja sama dengan orang lain untuk memenuhi kebutuhan dan sebagainya. Dengan demikian manusia akan berhubungan dan berinteraksi dengan orang lain dan individu dituntut untuk dapat berkomunikasi dengan baik. Dengan berkomunikasi dengan baik individu dapat diterima di lingkungannya.

Bagi siswa di sekolah, dituntut untuk dapat melakukan komunikasi interpersonal.. Siswa yang kurang mampu berkomunikasi lebih sering diam, menyendiri dan tidak mau bergabung dengan teman yang sedang mengobrol dengan teman yang lain. Hal ini terjadi akibat siswa mempunyai masalah yang sifatnya pribadi, salah satunya kurangnya pengetahuan tentang pentingnya komunikasi interpersonal bagi diri siswa. Padahal komunikasi interpersonal memiliki arti yang sangat penting yaitu, membantu perkembangan intelektual dan sosial kita.

Siswa SMK umumnya berkisar (16-19 th) dimana usia tersebut menurut Havighurst dalam Yusuf (2010:198) berada pada tahap usia remaja, yang mana salah satu tugas perkembangan yang harus dicapai adalah mengembangkan keterampilan komunikasi interpersonal. Dalam mengembangkan keterampilan hubungan dengan orang lain dapat dilakukan dengan cara membina pergaulan dalam kelompok maupun dengan lingkungannya, dan menciptakan proses interaksi sosial yang baik. Siswa dalam menciptakan interaksi sosial yang baik dituntut untuk memiliki kemampuan komunikasi interpersonal yang baik. 
Kemampuan komunikasi

interpersonal dapat menjadikan siswa berperilaku yang diterima oleh kelompok sosialnya.

Berdasarkan hasil

wawancara dengan guru BK SMK PGRI Wonoasri menunjukkan bahwa: (1) masih ada beberapa siswa yang berkomunikasi interpersonal kurang baik, (2) terjadi perselisihan antar siswa karena kesalahpahaman yang disebabkan komunikasi interpersonal yang kurang baik, (3) ada beberapa siswa yang tidak dapat mengendalikan diri dalam berperilaku dan berkomunikasi dengan siswa lain disekolah, (4) terdapat siswa yang cenderung diam dan menghindar pergaulan dengan teman sebayanya.

Upaya pembentukan keterampilan komunikasi interpersonal siswa tidak terlepas dari peranan bimbingan dan konseling di sekolah. Layanan bimbingan dan konseling di SMK mempunyai peran yaitu berperan secara maksimal dalam memfasilitasi peserta didik mengaktualisasikan segala potensi yang dimiliki. Dari berbagai jenis layanan dan media bimbingan, layanan bimbingan kelompok adalah layanan yang dipandang paling tepat digunakan untuk membantu siswa dalam meningkatkan komunikasi interpersonal siswa. Akan tetapi berdasarkan hasil wawancara dengan guru BK, layanan bimbingan kelompok masih belum maksimal. Guru BK disekolah menjelaskan dalam memberikan layanan bimbingan kelompok masih insidental, artinya tidak direncanakan secara terjadwal. Sehingga proses yang dilakukan belum sesuai dengan tahap-tahap yang ada pada pelaksanaan layanan bimbingan kelompok. Pelaksanaannya juga belum menggunakan teknik/metode tertentu. Hasil dari pelaksanaan layanan bimbingan kelompok juga tidak dilakukan evaluasi dan tindak lanjut. 
Dengan demikian bimbingan kelompok berbasis budaya Jawa merupakan salah satu intervensi yang direncanakan untuk membantu individu-individu melalui proses antar pribadi yang dinamis yang berorientasi pencegahan dan pengembangan. Melalaui bimbingan kelompok berbasis budaya Jawa diharapkan peserta didik mampu secara mandiri meningkatkan dan menggunakan pengetahuannya, mengkaji dan menginternalisasi serta mempersonalisasi nilai-nilai budayayang ada sehingga terwujud dalam perilaku seharihari.

Berdasarkan permasalahan di atas dan potensi budaya yang dapat diintegrasikan sebagai kekuatan dalam pelayanan bimbingan dan konseling, karena itu peneliti mengangkat judul dalam penelitian "Efektifitas Bimbingan Kelompok Berbasis Budaya Jawa untuk Meningkatkan Komunikasi Interpersonal Siswa SMK PGRI Wonoasri”.

\section{B. Kajian Pustaka \\ 1. Bimbingan Kelompok}

\section{a. Pengertian Bimbingan Kelompok}

Bimbingan kelompok merupakan bimbingan yang dilakukan secara kelompok terhadap sejumlah individu untuk mencegah timbulnya masalah dan mengembangkan potensi individu. Menurut Romlah (2006: 3) bimbingan kelompok adalah proses pemberian bantuan yang diberikan kepada individu dalam situasi kelompok. Artinya bahwa kegiatan bimbingan kelompok merupakan proses bantuan yang diberikan kepada sekolompok individu yang mengalami permasalahan yang sama.

\section{b. Tujuan Bimbingan}

\section{Kelompok}

Tujuan Bimbingan kelompok menurut Winkel \& Sri Hastuti (2010: 547)“adalah menunjang perkembangan pribadi dan 


$$
\begin{aligned}
& \text { perkembangan sosial } \\
& \text { masing-masing anggota } \\
& \text { kelompok serta } \\
& \text { meningkatkan mutu kerja } \\
& \text { sama dalam kelompok guna } \\
& \text { aneka tujuan yang bermakna } \\
& \text { bagi para partisipan”. } \\
& \text { MenurutWibowo } \\
& \text { (2005:17)tujuan bimbingan } \\
& \text { kelompok adalah: } \\
& \text { untuk memberi informasi } \\
& \text { dan data untuk } \\
& \text { mempermudah pembuatan } \\
& \text { keputusan dan tingkah laku, } \\
& \text { selanjutnya tujuan lain yang } \\
& \text { ingin dicapai adalah }
\end{aligned}
$$

\section{c. Tahapan Bimbingan \\ Kelompok}

Suatu proses layanan sangat ditentukan pada tahapan-tahapan yang harus dilalui sehingga akan terarah, runtut, dan tepat pada sasaran. Tahap pelaksanaan Bimbingan kelompok menurut Prayitno (2012: 170171) yaitu: a. Tahap pembentukan, yaitu tahapan untuk membentuk kerumunan sejumlan individu menjadi satu kelompok yang siap mengembangkan dinamika kelompok dalam mencapai tujuan bersama.

b. Tahap peralihan, yaitu tahapan untuk mengalihkan kegiatan kelompok ke kegiatan berikutnya yang lebih terarah pada pencapaian tujuan kelompok.

c. Tahap kegiatan, yaitu tahapan 'kegiatan inti' untuk membahas topik-topik tertentu.

d. Tahap penyimpulan, yaitu tahapan kegiatan untuk melihat kembali apa yang sudah dilakukan dan dicapai oleh kelompok. Peserta kelompok diminta melakukan refleksi berkenaan dengan kegiatan pembahasan yang baru saja diikuti.

e. Tahap penutupan, yaitu merupakan tahap akhir dari seluruh kegiatan. Kelompok merencanakan kegiatan bimbingan kelompok selanjutnya dan salam hangat perpisahan.

\section{Budaya Jawa}

\section{a. Konsep Budaya}

$$
\begin{aligned}
& \text { Sulasman (2013 :20) } \\
& \text { mendifinisikan budaya } \\
& \text { adalah suatu cara hidup yang } \\
& \text { berkembang dan dimiliki } \\
& \text { bersama oelh sekelompok }
\end{aligned}
$$


orang dan diwariskan dari

generasi ke generasi. Budaya

menjadi hal yang penting

untuk diperhatikan karena

telah diakui secara luas

bahwa budaya membawa

pengaruh bagi karakteristik

individu dan kelompok

individu. Prosser (dalam

Supriadi, 2001: 5)

menyatakan bahwa budaya

meliputi berbagai hal, mulai

dari tradisi, kebiasaan, nilai-

nilai, norma, bahasa,

keyakinan, dan berpikir yang

telah terpola dalam suatu

masyarakat dan diwariskan

dari generasi ke generasi

serta memberikan identitas

pada komunitas

pendukungnya.

b. Karakteristik Budaya Jawa

Manusia, masyarakat, kebudayaan dan sejarah merupakan empat komponen yang dapat dibedakan tetapi tidak dapat dipisahkan karena keempatnya berhubungan satu sama lain sebagai suatu sistem yang utuh. Manusia secara alami membentuk masyarakat yang pada tataran berikutnya bersama-sama menghasilkan kebudayaan yang kemudian ditulis dalam sejarah.

Bangsa Indonesia adalah bangsa yang majemuk terdiri dari beragam suku bangsa dan sub-suku bangsa, masing-masing dengan ciri kebudayaan yang partikular. Salah satu dari suku itu adalah orang jawa yang telah berabad-abad mengembangkan kebudayaannya.

Setiap budaya pasti memiliki kekhasannya sendiri yang sering kali menjadi ikon kebanggaan masyarakat pendukungnya. Jawa merupakan salah satu suku yang memiliki beragam kebudayaan yang khas. Masyarakat jawa lebih sering mengaktualisasikan sikap dan perilaku hidupnya ke dalam wujud yang tidak jelas (disamarkan) dengan menggunakan simbol-simbol tertentu. Penyampaian sikap 


\begin{abstract}
dan perilaku yang tersamarkan ini merupakan bentuk kehalusan budi masyarakat jawa. Orang jawa menggunakan budaya semu ini untuk menjaga jarak sosial, dimana diharapkan bahwa keretakan sosial akan terjaga melalui budaya semu yang halus. Dengan demikian orang jawa selalu berusaha menjalankan hidupnya dengan membahagiakan sesamanya. Budaya tidak dapat diajarkan melalui proses-proses kognitif, melainkan melalui pengembangan pembiasaan dan penanaman nilai secara inklusif yang terintegrasi dengan semua piranti pendidikan dan pembelajaran di sekolah.
\end{abstract}

\section{Daerah Mancanegari} adalah suatu sebutan untuk daerah-daerah di luar Surakarta Hardiningrat dan Yogyakarta Hardiningrat, yaitu Madiun, Kediri dan malang. Masyarakat yang hidup dalam peradaban ini disebut sebagai "tiyang pinggiran" (orang pinggiran). Daerah Mancanegari ini merupakan daerah pinggiran dari kebudayaan yang berkembang di kerajaan Jawa Mataram pada antara abad ke-17 hingga abad ke-19. Masyarakat Mancanegari memiliki kemiripankemiripan dengan masyarakat Negarigung dalam hal pementingan tutur bahasa dan keseniannya, kendatipun kualitasnya tidak sebaik atau sehalus peradaban kraton. Demikian juga soal pandangan keagamaannya (dahulunya dan mungkin sampai sekarang) ada kecenderungan kepada agama Kejawen.masyarakat yang Mancanegari merupakan perpaduan antara masyarakat Negarigung yang memiliki kehidupan keagamaan yang sinkretik, namun memiliki kebudayaan seperti masyarakat pesisir.

\section{c. Ajaran Budaya Jawa dalam}

\section{Bimbingan Kelompok}


Elemen-elemen di

dalam sebuah kebudayaan mencapai ratusan atau lebih dari itu, baik elemen budaya material maupun non materialnya. Pada elemen non material terkandung pula wujud gagas berupa AjarAn budaya yang jauh lebih sulit didefinisikan karena selain luas ruang lingkupnya juga karena sangat abstrak. Dalam bimbingan kelompok ini, Ajaran budaya Jawa yang dimaksud adalah Ajaran "Wong jowo nggone sewu ,Dhupak bujang esem mantra, Semu bupati, Sasmita narendra, Nguwongke lan diuwongke, Cacah agawe bubrah-Rukun agawe santoso, Rasa pangrasa" (Endraswara, 2012: 24).

\section{Komunikasi Interpersonal}

a. Pengertian Komunikasi

\section{Interpersonal}

\begin{tabular}{lr}
\multicolumn{3}{c}{ Komunikasi interpersonal } \\
adalah merupakan & proses \\
sosial dimana & individu- \\
individu yang & terlibat \\
didalamnya & saling
\end{tabular}

mempengaruhi. Seperti yang dikemukakan oleh De vito (2011:252) bahwa komunikasi interpersonal adalah merupakan pengiriman pesan-pesan dari seseorang dan diterima oleh orang lain, atau sekelompok orang dengan efek dan umpan balik yang langsung. Selanjutnya Supratiknya dalam Sugiyo (2005:3) menyatakan bahwa komunikasi interpersonal adalah setiap bentuk tingkah laku seseorang baik verbal maupun nonverbal yang ditanggapi oleh orang lain.

\section{b. Ciri-ciri Komunikasi \\ Interpersonal}

$$
\text { Depdikbud dalam Sugiyo }
$$

(2005: 4) mengemukakan bahwa ciri-ciri komunikasi interpersonal meliputi: (1) adanya peran serta, (2) adanya dialog bukan monolog, (3) adanya interaksi, (4) adanya ikatan psikologis.

Menurut De vito (2011:96) mengemukakan 
ciri-ciri komunikasi

interepersonal meliputi 5 ciri

yaitu: (1) Keterbukaan

(opennes), (2). Empati, (3)

Dukungan, (4) rasa positif (positiveness), (5) kesamaan (equality).

c. Tujuan

Komunikasi

\section{Interpersonal}

Menurut

Sugiyo

(2005:10)

tujuan dari

komunikasi interpersonal

adalah: (1) menemukan diri sendiri, (2) menemukan dunia luar, (3) membentuk dan memelihara hubungan yang bermakna dengan orang lain, (4) mengubah sikap dan perilaku sendiri dengan orang lain, (5) bermain dan hiburan, (6) belajar, (7) mempengaruhi orang lain, (8) merubah pendapat orang lain, (9) membantu orang lain.

\section{Metodologi Penelitian}

Penelitian

ini

dilaksanakan di SMK PGRI

Wonoasri yang beralamat di

Desa Wonoasri Kecamatan

Wungu Kabupaten Madiun.

Penelitian ini menggunakan pendekatan kuantitatif karena menekankan fenomenafenomena yang objektif dan dikaji secara kuantitatif. Untuk memaksimalkan objektifitasnya dengan menggunakan angkaangka dan pengelohan statistik.Desain penelitian yang digunakan dalam penelitian ini adalah penelitian eksperimen. Desain eksperimen yang dipakai adalah pre-experimental design. Dalam desain eksperimen ini hanya terdapat 1 kelompok, tidak terdapat kelompok kontrol.

Populasi dalam penelitian ini adalah siswa kelas $\mathrm{X}$ AK yang berjumlah siswa.Teknik pengambilan sampel yang akan digunakan adalah porposive random sampling, berdasarkan tujuan penelitian yaitu siswa yang memiliki komunikasi interpersonal rendah berjumlah 8 siswa akan dijadikan subjek penelitian atau sampel penelitian.

Menurut Sugiono (2011, 147) instrument penelitian adalah "suatu alat yang 
digunakan untuk mengukur

fenomena alam maupun sosial yang diamati”. Teknik pengumpulan data yang digunakan dalam penelitian ini adalah skala psikologis. Skala psikologis dalam penelitian ini berbentuk skala sikap dimana hanya mengukur sikap, maka instrumen penelitian akan lebih menekankan pada pengukuran sikap yaitu komunikasi interpersonal siswa.

Skala pengukuran komunikasi interpersonal yang digunakan pada penelitian ini adalah adalah skala Likert, yaitu skala yang digunakan untuk mengukur sikap, pendapat, persepsi seseorang atau sekelompok tentang kejadian atau gejala sosial.

Analisis data kuantitatif ini untuk menguji keefektifan bimbingan kelompok berbasis budya jawa dalam meningkatkan keterampilan komunikasi

interpersonal siswa, maka teknik analisis data dalam penelitian ini meggunakan Wilcoxon Match Pairs Test.

\section{Hasil Penelitian}

Angket kecenderungan komunikasi interpersonal siswa SMK PGRI Wonoasri, Kabupaten Madiun sebelum diterapkan layanan bimbingan kelompok berbasis budaya Jawa menunjukkan sebagian besar berada pada kriteria rendah. Diketahui dari hasil pre test yang telah dilakukan ada satu siswa termasuk dalam kategori sangat rendah dengan skor 43 - 68,8dan tujuh siswa dalam kategori rendah dengan skor 68,9 - 94,6. Secara keseluruhan skor ratarata komunikasi interpersonal siswa SMK PGRI Wonoasri sebelum diterapkan layanan bimbingan kelompok berbasis budaya Jawa termasuk dalam kategori rendah. 
Skor sub variabel komunikasi interpersonalsebelum diterapkan layanan bimbingan kelompok berbasis budaya Jawa

\begin{tabular}{|c|l|c|c|}
\hline No & \multicolumn{1}{|c|}{ Sub Variabel } & Skor & Kategori \\
\hline 1 & Keterbukaan & 13 & Rendah \\
\hline 2 & Empati & 13 & Rendah \\
\hline 3 & Dukungan & 13 & Rendah \\
\hline 4 & Positif & 14 & Rendah \\
\hline 5 & Kesamaan & 14 & Rendah \\
\hline & Skor rata-rata & 13,4 & Rendah \\
\hline
\end{tabular}

Berdasarkan tabel 4.3, sebelum diterapkan layanan bimbingan kelompok berbasis budaya Jawa, skor komunikasi interpersonal siswa pada sub variabel keterbukaan sebesar 13, sub variabel empati sebesar 13, sub variabel dukungan sebesar 13, sub variabel positif 14 dan sub variabel kesamaan sebesar 14. Kelima sub variabel tersebut termasuk pada kategori rendah, sedangkan pada skor rata-rata sebesar 13,4 dan termasuk dalam kategori rendah.

Berdasar hasil pretest tersebut peneliti tergugah untuk memberikan sebuah intervensi agar komunikasi interpersonal siswa dapat meningkat, yaitu dengan bimbingan kelompok berbasis budaya. Dari hasil intervensi diperoleh hasil (posttest) yang dapat dilaporkan sebagai berikut.

Tabel 4.4

Tingkat Komunikasi InterpersonalSiswa Sebelum Diterapkan layanan bimbingan kelompok berbasis budaya Jawa

\begin{tabular}{|c|c|c|c|}
\hline Skor & Kriteria & Jumlah Sampel & Prosentase \\
\hline $43-68,8$ & Sangat rendah & 0 & 0 \\
\hline
\end{tabular}




\begin{tabular}{|c|c|c|c|}
\hline $68,9-94,6$ & Rendah & 0 & 0 \\
\hline $94,7-120,4$ & Sedang & 1 & 12,5 \\
\hline $120,5-146,2$ & Tinggi & 7 & 87,5 \\
\hline $146,3-172$ & Sangat tinggi & 0 & 0 \\
\hline \multicolumn{2}{|c|}{ Jumlah } & 8 & 100 \\
\hline
\end{tabular}

Sesuai dengan tabel 4.4 kecenderungan komunikasi interpersonal siswa SMK PGRI Wonoasri, Kabupaten Madiun setelah diterapkan layanan bimbingan kelompok berbasis budaya Jawa menunjukkan sebagian besar berada pada kriteria tinggi. Diketahui dari hasil post test yang telah dilakukan ada satu siswa termasuk dalam kategori sedang dengan skor 94,7 - 120,4 dan tujuh siswa dalam kategori tinggi dengan skor 120,5 146,2. Secara keseluruhan skor rata-rata komunikasi interpersonal siswa SMK PGRI Wonoasri stelah diterapkan layanan bimbingan kelompok berbasis budaya Jawa termasuk dalam kategori tinggi.

Tabel 4.5

Skor sub variabel komunikasi interpersonalsetelah diterapkan layanan bimbingan kelompok berbasis budaya Jawa

\begin{tabular}{|c|l|c|c|}
\hline No & \multicolumn{1}{|c|}{ Sub Variabel } & Skor & Kategori \\
\hline 1 & Keterbukaan & 25 & Tinggi \\
\hline 2 & Empati & 26 & Tinggi \\
\hline 3 & Dukungan & 25 & Tinggi \\
\hline 4 & Positif & 26 & Tinggi \\
\hline 5 & Kesamaan & 25 & Tinggi \\
\hline \multicolumn{2}{|l}{ Skor rata-rata } & 25,4 & Tinggi \\
\hline
\end{tabular}


Berdasarkan tabel 4.5, Berdasarkan hasil analisis setelah diterapkan layanan bimbingan kelompok berbasis budaya Jawa, skor komunikasi interpersonal siswa pada sub variabel keterbukaan sebesar 25 , sub variabel empati sebesar 26, sub variabel dukungan sebesar 25, sub variabel positif 26 dan sub variabel kesamaan sebesar 25. Kelima sub variabel tersebut termasuk pada kategori tinggi, sedangkan pada skor rata-rata sebesar 25,4 dan termasuk dalam kategori tinggi.

menunjukkan terjadinya perubahan pada kondisi awal komunikasi interpersonal siswa, ditandai dengan adanya peningkatan skor skala komunikasi interpersonal siswa baik pada skor total maupun skor setiap indikator. Adapun peningkatan komunikasi interpersonal siswa antara kondisi awal dan kondisi akhir dapat dilihat pada tabel berikut:

Tabel 4.6

Perubahan Komunikasi Interpersonal Siswa antara Pretest dan Post-test

\begin{tabular}{|c|c|c|c|c|c|c|}
\hline \multirow{2}{*}{ Nama } & \multicolumn{2}{|c|}{ Pre test } & \multicolumn{2}{c|}{ Post Test } & \multicolumn{2}{c|}{ Perubahan } \\
\cline { 2 - 7 } & Skor & $\%$ & Skor & $\%$ & Skor & $\%$ \\
\hline 1 & 69 & 40 & 140 & 81 & 71 & 41 \\
\hline 2 & 72 & 42 & 146 & 85 & 74 & 43 \\
\hline 3 & 73 & 42 & 138 & 80 & 65 & 23 \\
\hline 4 & 76 & 44 & 107 & 62 & 31 & 13 \\
\hline 5 & 68 & 40 & 138 & 80 & 70 & 30 \\
\hline 6 & 75 & 44 & 143 & 83 & 68 & 24 \\
\hline 7 & 76 & 44 & 143 & 83 & 67 & 23 \\
\hline 8 & 73 & 42 & 136 & 79 & 63 & 21 \\
\hline$\sum$ & 73 & 42 & 136 & 79 & 64 & 27 \\
\hline
\end{tabular}


Agar lebih mudah dalam

melihat perubahan kondisi awal dan

kondisi akhir tingkat komunikasi interpersonal siswa dapat dilihat

pada grafik sebagai berikut:

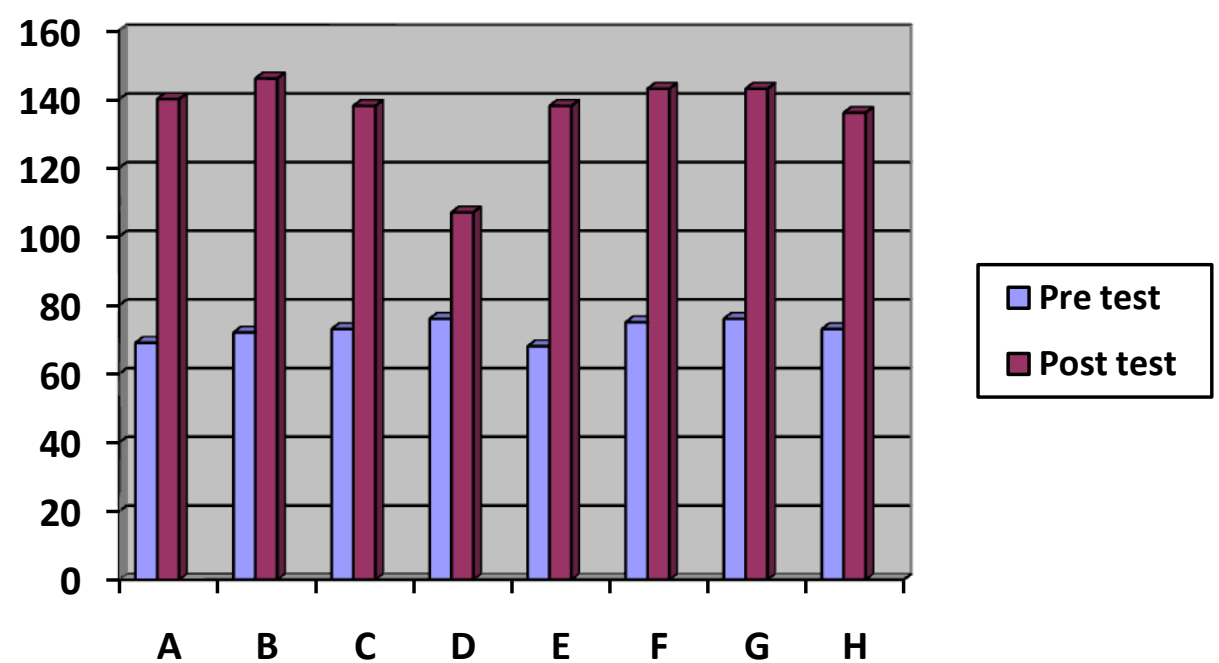

Gambar 4.1 DiagramSkor PretestdanPostest Tingkat Pemahaman Karier

\begin{abstract}
Dari gambar4.1 diatas dapat dijelaskan bahwa terjadi peningkatan komunikasi interpersonal siswa antara sebelum dan sesudah diberikan layanan bimbingan kelompok berbasis budaya Jawa. Rata-rata perubahan yang terjadi adalah sebesar 64 atau sekitar 27\%, dari data pretest sebesar 73atau $42 \%$ menjadi 136 atau 79\%. Rata-rata setiap aspek tingkat komunikasi iterpersonal siswa sebelum diberi layanan berada pada kategori rendah, setelah
\end{abstract}

diberikan layanan bimbingan kelompok berbasis budaya Jawa terjadi peningkatan menjadi kategori tinggi. Ini berarti bahwa layanan bimbingan kelompok berbasis budaya Jawa efektif untuk meningkatkan komunikasi interpersonal siswa SMK PGRI Wonoasri.

Untuk menguji keefektifan bimbingan kelompok berbasis budaya Jawa dilakukan dengan teknik statistik non-parametris, yaitu menggunakan Tes Ranking Bertanda (Wilcoxon Signed Rank 
Test) dengan menggunakan program SPSS. Wilcoxon Signed Rank Test digunakan untuk menguji signifikasi hipotesis komparatif 2 sampel yang berkorelasi bila datanya berbentuk ordinal dan atau berjenjang (Sugiyono, 2013: 137). Hasil perhitungan melalui SPSS sebagai berikut :

Tabel 4.7Perhitungan uji Wilcoxon Signed Rank Test dengan SPSS

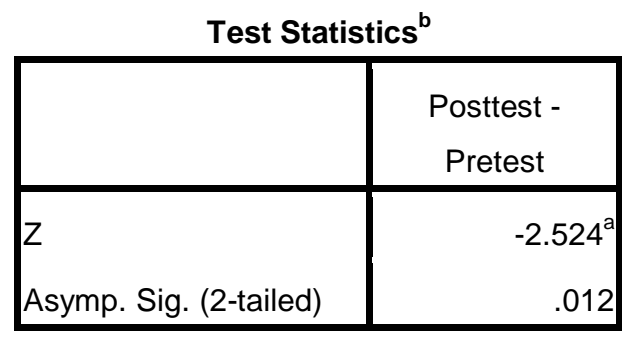

a. Based on negative ranks.

b. Wilcoxon Signed Ranks Test

Berdasarkan hasil output test stastistik di atas diperileh nilai Asymp. Sig (2 tailed) sebesar 0,012. Karena nilai sig $0,012<0,05$ maka dapat disimpulkan bahwa ada perbedaan tingkat komunikasi interpersonal siswa antara sebelum dan sesudah mendapatkan layanan bimbingan kelompok berbasis budaya jawa, dengan ini maka hipotesis alternatif diterima yang berbunyi "Bimbingan kelompok berbasis budaya Jawa efektif untuk meningkatkan komunikasi interpersonal siswa SMK PGRI Wonoasri.

\section{E. Kesimpulan dan Saran}

Berdasarkan analisis data yang berhasil dikumpulkan melalui assesment, dianalisis dengan statistik dengan menghitung prosentase. Dari hasil pre-test diketahui bahwa di SMK AK wonoasri terdapat permasalahan masih rendahnya komunikasi Interpersonal, yaitu sebesar $40 \%$ yang memiliki komunikasi interpersonal. Oleh karena itu perlu sebuah terobosan baru untuk meningkatkan komunikasi interpersonal pada siswa SMK AK Wonoasri. Disini peneliti memiliki gagasan untuk mengaplikasikan bimbingan kelompok berbasis budaya jawa sebagai upaya peningkatan komunikasi interpersonal siswa 
Dari hasil penelitian ini dapat diberikan saran-saran sebagai berikut:

1. Diharapkan bagi ilmuwan psikologi khususnya psikologi pendidikan, bisa menjadikan penelitian ini sebagai masukan bagi peneliti-peneliti lain yang ingin meneliti jenis bidang yang sama.

2. Bagi partisipan baik yang mengikuti maupun yang tidak mengikuti, diharapkan penelitian ini dapat memberikan sumbangan informasi mengenai cara meningkatkan komunikasi interpersonal siswa SMK dengan menggunakan bimbingan kelompok berbasis budaya jawa.

\section{DAFTAR PUSTAKA}

De vito. 2011. Komunikasi Antar Manusia. Tangerang: Karisma Publishing Group

Endraswara, Suwardi. 2012. Falsafah Hidup Jawa. Yogyakarta: Cakrawala

Gibson, R. L dan Mitchell, M. H. 2011. Introduction to Counseling and Guidance.
Diterjemahkan oleh Yudi Santoso. Yogyakarta: Pustaka Pelajar.

Mulyana, D, dan J, Rakhmat. 2006. Komunikasi Antarbudaya: Panduan Berkomunikasi dengan orang-orang Berbeda Budaya. Bandung: Rosdakarya.

Prayitno. 2004. Pedoman Bimbingan Kelompok. Padang: Universitas Padang Press

Prayitno. 2012. Layanan Bimbingan dan Konseling Kelompok: Dasar dan Profil. Jakarta: Ghalia Indonesia

Rakhmat, Djalaludin. 2005. Psikologi Komunikasi. Bandung:PT Rosdakarya

Romlah, Tatiek. 2006. Teori dan Praktik Bimbingan Kelompok. Malang: Universitas Negeri Malang.

Sugiyo. 2005. Komunikasi Antar Pribadi. Semarang: UNNES Press

Sugiyono. 2010. Metode Penelitian Kuantitatif Kualitatif dan $R \& D$. Bandung: Alfabeta.

Sukardi. Dewa Ketut. 2008. Pengantar Pelaksanaan Program Bimbingan dan Konseling disekolah. Jakarta: Rineka Cipta.

Supriadi, Dedi. 2001. Konseling Lintas Budaya: Isu-isu dan Relevansinya di Indonesia. Bandung:UPI 
Tohirin. (2011). Bimbingan dan Konseling di Sekolah dan Madrasah. Jakarta : PT Rineka Cipta.

Willis, Sofyan. 2012. Psikologi Pendidikan.

Bandung:Alfabeta
Wibowo, Mungin Eddy. 2005. Konseling Kelompok Perkembangan. Semarang: Unnes Press.

Yusuf, Syamsu. 2010. Landasan Bimbingan dan Konseling. Bandung: PT. Remaja Rosdakarya 